\title{
Disposal of layer droppings reared in case and impact on environmental pollution
}

\author{
M. Abdullah-Al-Amin, M. S. Rahman, M. A. R. Howlider, M. M. Ahmmed \\ Department of Poultry Science, Bangladesh Agricultural University, Mymensingh-2202, Bangladesh
}

\begin{abstract}
A study evaluated the droppings disposal in layer farm and measures adapted to protect environmental pollution. Data were collected from 20 randomly selected layer farmers by a semi structured personal interview schedule from Sadar upazilla of Mymensingh. The independent variables such as age and gender of farmers, family size educational qualification occupation etc. and the dependent variables such as flock size, age of birds, feed consumption, egg and dropping production, cleaning of dropping etc. were studied. The feed consumption and droppings production/layer/day were 116.54 and $151.65 \mathrm{~g}$, respectively. Hen housed egg production was $80.55 \%$. The cost for cleaning, price of droppings and profit on droppings sale/layer/day were Tk $0.01,0.07$ and 0.07 respectively. Half of farmer received maximum earning from droppings in winter. Most of the farmers had single storied house and used ceiling fan. Most of the farmers clean droppings in alternate day in the morning by the male worker using belcha to minimize environmental pollution and half of them used disinfectants. Average time required/day to clean droppings was 83.00 minute. Majority of the farmer consider cleaning of droppings to be a real problem for odour and gas $\left(\mathrm{NH}_{3}\right)$ emission. Majority farmers stored droppings at high land as an open pit. Average distance between pit and shed was $58.33 \mathrm{~m}$. The highest proportion of the farmers used droppings in the crop field by composting while others sold to fisheries. Majority of the respondents opined that feed, droppings, dead birds, medicinal wastes and odour do not cause environmental pollution. Droppings disposal is a real problem for aesthetic, public safety and environmental point of view. Cleaning technique and tools needed to be modernized for efficient and cost effective cleaning. Standard method needed to be introduced for proper treatment and use of droppings to maximize its use and benefit.
\end{abstract}

Keywords: Droppings disposal, Environmental pollution, Caged rearing

\section{Introduction}

Poultry industry in Bangladesh is developing rapidly since 1980. At present, there are about 0.15 million poultry farmers and 6 million livelihoods directly depend on poultry industry (Rahman, 2007). The total population of poultry is $200-220$ million and the daily waste produced from this industry is $15-20$ million ton (Bhuyian, 2007). In general, for each $\mathrm{kg}$ of feed consumed, a chicken approximately produces $1 \mathrm{~kg}$ of fresh manure with variable water content, while a commercial layer produces about $20 \mathrm{~kg}$ waste per year (Vest et al., 1994). Lack of proper disposal of the voluminous excreta is creating environmental and health hazards and spread foul smell in the adjoining areas of the poultry farms. Sometimes local communities complain against farms, may become threat to the sustainability of poultry industries. The amounts of layer droppings are increasing day by day with rapid increase of layer population (Khaleduzzaman and Khandaker, 2009). So, layer droppings created an endangered urban life and deteriorate the daily life of people with a consequent degradation of the environment. The concept of layer droppings disposal has taken a new dimension and emphasis has been given on proper layer droppings disposal, which is not only profitable but also environment friendly. The situation of layer droppings management is inefficient in developing and under developed countries than that in developed countries. Developed countries can spend a lot of money for layer droppings management and they are also able to use develop technologies that help better management of droppings. The people of developed country are more conscious about droppings management and they maintain a hygienic system which reduces hazards. On the other hand, the situation is much complicated in developing countries including Bangladesh for illiteracy, unconscious and lower per capita income. They face various hygienic and environmental problem for poor layer droppings management.

Now a day's environmental pollution is a great threat in our country. Layer dropping is now a factor to pollute environment. If could manage properly, it would be an asset to us. As nutrient rich products, the droppings needed to be managed in a sustainable manner without causing environmental pollution. Layer droppings could be used as organic manure for crops, vegetables and psiculture (Sarker, et al., 2009). There is a lack of information on the layer droppings disposal and their impact on environment pollution. Therefore, the present study was under taken to know the layer droppings disposal and precautions need to be adapted in protecting environmental pollution. 


\section{Materials and Methods}

The study was conducted in Mymensingh Sadar Upazilla. A semi structured and pre-tested interview schedule was used to collect data. Necessary correction, modification and alterations were done accordingly. Data were collected through personal interview during July to December 2008. Two types of variables; (independent and dependent) were selected. The independent variables were age, gender, family size, educational qualification, occupation, training on poultry farming, farm size, age of neighbour, education of neighbour, relationship between the farmer and the neighbour. The dependent variables were flock size, age of bird, age at laying, age at transfer into the cage, age at culling spent hen, feed requirement, hen housed egg production, droppings production, time required/day to clean droppings, cost to clean droppings, distance between disposal pit and shed, sale of droppings $/ 50 \mathrm{~kg}$ bag, sale of droppings/layer/day, profit of droppings, age group of bird, type of housing, type of ventilation, frequency of droppings collection, time of cleaning, cleaning responsibility, problem for cleaning, type of problem, tool for cleaning, disinfectant use, seasonal problem, site of disposal, neighbor's complain, pit location, upper side of the pit, apply field (compost), composting period, treatment of droppings, use of droppings, droppings collected at free cost, droppings buyer, maximum droppings price, inclusion of dropped feather into droppings, pollution by feed, pollution by droppings, pollution by dead hen, pollution by medical wastes, pollution by bad odour, measure for least pollution of dropping, face any problem by poultry farming, type of problem and distance of spreading odour from the farm. The responses of the respondents that were recorded in the interview schedule were transferred into a master sheet for entering the data in the computer. The SPSS computer programmed was used for analysis of data. Various descriptive statistical measures such as number and percentage distribution, range, mean and standard deviation were calculated. Simple tabular techniques were used to explain the data. Minimum, maximum, mean, standard deviation and percentage for quantitative variables and Chi-square test and percentage for qualitative variables were used to illustrate the results.

\section{Results and Discussion}

The findings of the study and their logical interpretations are presented in three sections.

\section{Selected characteristics of layer farmer}

The purpose of this section is to have an understanding on selected characteristics of the respondent.

Age: The age of respondent ranged from 31 to 55 year with an average of 42.70 (Table 1). Based on their age, respondents were classified into young (up to 29 years), middle age (between 30 and 50) and old aged (above 50 years). The highest proportion (90\%) was middle aged, while rest belonged to old. Absence of young farmer might be due to the fact that young farmers are not economically solvent and lack of experience and confidence to run poultry farm. Poorer participation of older persons may be related to their inferior physical fitness. Less participation of older person in poultry farming has been supported by Shahidullah (1987) and Hamid (1997).

Gender: Predominantly males were the owner of the layer farms. Hesitation in decision making and religious bindings in working outside appear to be the major constraints for women to participate in poultry farming. Such assumption has been supported by Azad (2003).

Family size: The family size of the respondent ranged from 1 to 7 members (Table 1) with an average of 4.40. On the basis of their family size, respondents were classified into "Small family" (up to 4), "medium family" (5-6) and large family (above 6). Fifty per cent of the respondents had small families, 45 per cent had medium family and 5 per cent had large families. An average family size found is lower than that of the national average of 4.71 (BBS, 2007). Existence of small and medium family size may be due to the well adoption of family planning and also may be some of the respondent lived in a separate family.

Education: The education scores of the respondent ranged from 8 to 14 with an average of 11.05. Large proportion of the respondent had secondary education (Table 1). The rest had higher education. The literacy rate of Bangladesh is 53.1 per cent (BBS, 2007). Possession of some education by the majority of the respondent is a positive aspect in the proper dropping management and environment to gain knowledge by reading books, leaf lets, bulletins and other printing materials. 
Main occupation: The main occupations of the respondents are business, farmer and jobs. The height proportion of the respondents in the study area was business, $20.0 \%$ farmer and $10.0 \%$ doing jobs $(P<0.01)$. This findings signal that business men are economically solvent enough to establish layer farm. Participation of business communities in poultry farming also signal that layer operation is certainly a profitable enterprise.

Training on farm management: In the study area, $50.0 \%$ of the respondents were trained, while $50.0 \%$ were non trained. Such a scenario impress that farmers are realizing the importance of training. Akteruzzaman et al. (2009) suggested that the farmers having training exposure earned more money than the farmers of having no training.

Farm size: The farm sizes of the respondents varied from 2.5 to 78 decimal with an average of 17.08 . It is revealed that majority of the respondents had small farm, while $15 \%$ possessed medium and $5 \%$ possessed large farm. The standard deviation might indicate that farm size showed wide variation .

Flock size: Flock size varied from 200 to 8500 birds with an average of 1770 birds with three categories (Table 1). Majority (50.0\%) of the respondents had medium flock, $35.0 \%$ possessed small flock and $15.0 \%$ possessed large flock having wide variation possibly due to variable farm size, investing capacity and/or managerial ability.

Table 1. Selected characteristics of layer farmer of Mymensingh Sader Upazilla

\begin{tabular}{|c|c|c|c|c|c|c|c|}
\hline \multirow[t]{2}{*}{ Items } & \multirow[t]{2}{*}{ Category } & \multicolumn{2}{|c|}{$\begin{array}{l}\text { Respondents } \\
\quad(n=20)\end{array}$} & \multirow[t]{2}{*}{ Mean } & \multirow[t]{2}{*}{ SD } & \multirow[t]{2}{*}{ Chi-test } & \multirow[t]{2}{*}{$\begin{array}{l}\text { Observed } \\
\text { range }\end{array}$} \\
\hline & & Number & $\%$ & & & & \\
\hline \multirow{3}{*}{$\begin{array}{l}\text { Age of respondent } \\
\text { (years) }\end{array}$} & Low $(<30)$ & 0 & 0.0 & \multirow[t]{3}{*}{42.70} & \multirow[t]{3}{*}{7.183} & & \multirow[t]{3}{*}{$31-55$} \\
\hline & \begin{tabular}{|l|} 
Middle (30-50) \\
\end{tabular} & 18 & 90.0 & & & & \\
\hline & High (>50) & 2 & 10.0 & & & & \\
\hline \multirow[t]{2}{*}{ Gender of farmer } & Male & 18 & 90.0 & & & \multirow[t]{2}{*}{$12.80^{* *}$} & \\
\hline & Female & 2 & 10.0 & & & & \\
\hline \multirow[t]{3}{*}{ Family size (No.) } & Small $(<5)$ & 10 & 50.0 & \multirow[t]{3}{*}{4.40} & \multirow[t]{3}{*}{1.569} & & \multirow[t]{3}{*}{$1-7$} \\
\hline & Medium (5-6) & 9 & 45.0 & & & & \\
\hline & Large $(>6)$ & 1 & 5.0 & & & & \\
\hline \multirow[t]{3}{*}{ Level of education } & Primary $(\leq 5)$ & 0 & 0.0 & \multirow[t]{3}{*}{11.05} & \multirow[t]{3}{*}{2.114} & & \multirow[t]{3}{*}{$8-14$} \\
\hline & Secondary (6-10) & 12 & 60.0 & & & & \\
\hline & Higher $(>10)$ & 8 & 40.0 & & & & \\
\hline \multirow[t]{3}{*}{ Main occupation } & Farmer & 4 & 20.0 & & & \multirow[t]{3}{*}{$12.41^{* *}$} & \\
\hline & Business & 14 & 70.0 & & & & \\
\hline & Jobs & 2 & 10.0 & & & & \\
\hline \multirow{2}{*}{$\begin{array}{l}\text { Training on farm } \\
\text { management }\end{array}$} & Yes & 10 & 50.0 & & & & \\
\hline & No & 10 & 50.0 & & & & \\
\hline \multirow[t]{3}{*}{ Farm size (decimal) } & Small $(<25)$ & 16 & 80.0 & \multirow[t]{3}{*}{17.08} & \multirow[t]{3}{*}{19.115} & & \multirow[t]{3}{*}{$2.5-78$} \\
\hline & Medium (25-50) & 3 & 15.0 & & & & \\
\hline & Large (>50) & 1 & 5.0 & & & & \\
\hline \multirow[t]{3}{*}{ Flock size } & Small $(<1000)$ & 7 & 35.0 & \multirow[t]{3}{*}{1770} & \multirow[t]{3}{*}{2008.102} & & \multirow[t]{3}{*}{$200-8500$} \\
\hline & Medium (1000-2000) & 10 & 50.0 & & & & \\
\hline & Large $(>2000)$ & 3 & 15.0 & & & & \\
\hline
\end{tabular}

**, $\mathrm{P}<0.01$

\section{Characteristics of layer farm}

The purpose of this section is to have an understanding on selected characteristics of layer farm.

Age of birds: Age of birds ranged from 24 to 72 weeks with an average of 46.40 . The finding indicated that age of bird among the farms had wide variation. Such difference might be due to different starting time of layer flock. 
Age of shifting into the cage: Age of shifting into the cage of bird ranged from 8 to 20 week with an average of 12.35. This variation might be due to lack of unified perception, and recommendation. Placing of pullets in laying cages at 14 weeks of age has been reported by Bell and Weaver (2002) which is almost close to the average age of placing pullets in laying cages in the current study.

Age at start laying: Age at start laying of bird ranged from 18 to 22 weeks with an average of 19.55 . This variation might be due to difference of strain, feeding, lighting and management.

Age at culling spent hen: Age at culling spent hen ranged from 65 to 82.5 weeks with an average of 78.48 (Table 2). Age at culling may vary due to availability of replacement pullet, difference in production level of the flocks and price of eggs. Bell and Weaver (2002) opinioned that optimum age is between 75 and 80 weeks for culling spent hen.

Table 2. Characteristics of layer farm in relation to performance and droppings production

\begin{tabular}{|l|c|c|c|}
\hline Item & Mean & Standard deviation & Observed range \\
\hline Current age of bird (week) & 46.40 & 15.739 & $24-72$ \\
\hline Age at start laying (week) & 19.55 & 1.376 & $18-22$ \\
\hline Age shift into the cage (week) & 12.35 & 3.372 & $8-20$ \\
\hline Age at cull spent hen (week) & 78.48 & 4.018 & $65-82.5$ \\
\hline Feed intake (g)/ layer/day & 116.54 & 5.134 & $100-125$ \\
\hline Hen housed egg production (\%) & 80.55 & 7.970 & $63-92$ \\
\hline Droppings production/ layer/day (g) & 151.65 & 12.874 & $129.40-177.78$ \\
\hline Time required/day to clean droppings (min) & 83.00 & 40.536 & $30-180$ \\
\hline Cost to clean droppings/ layer/day (Tk.) & 0.012 & 0.008 & $0.0044-0.0313$ \\
\hline Distance between disposal pit and shed (m) & 58.33 & 73.785 & $1.52-249.64$ \\
\hline Sale of droppings per 50 kg bag (Tk). & 24.50 & 16.057 & $10.00-53.03$ \\
\hline Sale of droppings /layer/day (Tk.) & 0.074 & 0.044 & $0.03-0.15$ \\
\hline Profit of droppings /layer/day (Tk.) & 0.065 & 0.048 & $0.0175-0.1437$ \\
\hline
\end{tabular}

Feed intake: Feed intake/bird/day ranged from 110 to $125 \mathrm{~g}$ mash with an average of 116.54 . Feed requirement may vary due to variation in the body weight, environmental temperature, amount of bird activity, variation in egg production, difference in egg size, prevalence of stress, age of the birds, amount of feather cover and strain (Bell and Weaver, 2002).

Hen housed egg production: Hen housed egg production ranged from 63 to 92 per cent with an average of 80.55 . Such wide variation might have been arisen for the variation of starting age, feeding, culling age, environment and management. Low production recorded may be due to late culling and/or poor management. Early culling and/or good management given to strains of high potentiality might be responsible for good production. Hen housed egg production vary due to strain, temperature, stress, mortality, number of birds per cage, cage floor space and many other factors (North and Bell, 1990).

Droppings production: Droppings production/bird/day ranged from 129.40 to $177.78 \mathrm{~g}$ with an average of 151.65 impress that droppings production/bird/day had wide variation. Variation in droppings production may be for variation of feed intake, water intake, environment and age of birds. North and Bell (1990) suggested that variation in droppings production could be attributed to variation of feed consumption, water consumption, composition and form of feed, humidity and temperature.

Time required/day to clean droppings: Time required for cleaning droppings ranged from 30 to 180 minutes with an average of 83.00 . This variation might be related to difference of farm size, flock size, distance between shed \& site of disposal and efficiency of labour.

Cost to clean droppings: Cost to clean droppings/bird/day (Table 2) ranged from Tk 0.0044 to 0.0313 with an average of 0.012 . Narrow variation of cost may be attributed to similarity of labour cost and labour efficiency in a given area.

Distance between disposal pit and shed: Distance between disposal pit and shed ranged from 1.52 to $249.64 \mathrm{~m}$ with an average of 58.33 showing a wide variation. This variation might be due to difference of knowledge, awareness and facility available to the farmers. 
Sale of droppings per $\mathbf{5 0} \mathrm{kg}$ bag: The price of droppings per $50 \mathrm{~kg}$ bag ranged from Tk 10.00 to 53.03 with an average of 24.50 (Table 2) indicated a wide variation. Such a variation may be functions of carrying distance, communication and distance between farm and users.

Sale of droppings/layer/day: Price of droppings/layer/day ranged from Tk 0.03 to 0.15 with an average of 0.074 showing a narrow variation. Narrow variation of price may be attributed to consensus development.

Profit from droppings: The profit of droppings /layer/day ranged from Tk 0.0175 to 0.1437 with an average of 0.065 (Table 2). This result signified that droppings should not be considered as a liability but it is an asset to the farmers. Thus, proper disposal of droppings appeared to be feasible and profitable.

\section{Dropping management among the farmers}

The purpose of this section is to have an understanding the selected characteristics of dropping management among the farmers.

Age group of birds: Most of the layer farmer rear birds at the same age group (90.0\%) and rest rear birds of different age groups (10.0\%). The result indicated that birds of same age group were significantly higher than birds of different ages. For maintenance of bio-security, same age of bird should be reared.

Type of housing: There are two types of house; single storied and multi-storied. Among the farmers, $85.0 \%$ had single storied house, $10.0 \%$ had multi-storied house, $5.0 \%$ had both single storied and multistoried house. Single storied house appeared to be traditional and conventional possibly for its less cost and easy cleaning facilities.

Type of ventilation: There are three types of fan used for ventilation; ceiling fan, table fan and standing fan. Among farmers, $75.0 \%$ used ceiling fan, $15.0 \%$ used ceiling \& stand fan, $5.0 \%$ used ceiling \& table fan and $5.0 \%$ used ceiling, table \& standing fan. The finding indicated that most of the farmer use ceiling fan for ventilation $(P<0.01)$. Abundant use of ceiling fan may be for its simplicity, availability and cheapness.

Frequency of droppings collection and time of cleaning: Most of the layer farms $(60.0 \%)$ collect droppings in alternative day, $35.0 \%$ collect every day and the rest two days interval (5.0\%). Droppings collection in alternative day seemed to be traditional. Most of the layer farms clean droppings in the morning $(90.0 \%)$, and rest at noon (10.0\%). Cleaning droppings in the morning is appeared to be traditional and convenient.

Cleaning responsibility: Among the cleaners, $70.0 \%$ were male labour, $10.0 \%$ female labour, $10.0 \%$ male farmer and $5.0 \%$ is farmer's wife \& $5.0 \%$ is buyer. The finding indicated that male labours were significantly higher than that of others.

Problem for cleaning: Majority of the farmer $(70 \%)$ consider cleaning of droppings to be a real problem. In Bangladeshi society cleaning droppings is consider as a nuisance and not at all consider as a prestigious job. Among farmers, $50 \%$ faced odour problem in cleaning droppings, while other $50 \%$ faced gas $\left(\mathrm{NH}_{3}\right)$ problem irritating eyes. Farms with frequent manure removal generally have minimal odour problems (Bell and Weaver, 2002). It was found that $60 \%$ respondents reported dropping cleaning to be problematic in winter and $40 \%$ found it problematic in summer.

Tools for cleaning: It was observed that $85 \%$ respondents used belcha for cleaning droppings while, $15 \%$ used belcha and water for cleaning droppings. Belcha used for cleaning droppings was significantly higher than belcha and water $(P<0.01)$. Water with pressure is needed for proper cleaning of poultry premises. Such a facility is not available in Bangladesh. That may be reason for predominant use of belcha to use in farm cleaning.

Use of disinfectant: Among farmers, $15.0 \%$ used savlon, $10.0 \%$ phenol, $10.0 \%$ potash, $5.0 \%$ potash \& savlon, $5.0 \%$ potash \& bleaching powder, $5.0 \%$ potash, savlon \& bleaching powder, other $25.0 \%$ used unknown disinfectants and $25.0 \%$ do not use any disinfectant. There is no specific fascination, choice or recommendation for disinfectants among the farmers. 
Site of disposal: Site of disposal for layer droppings is too much crucial for management system and environmental protection. Environments are polluted by the haphazard storage. Among farmers, 83.3\% store in pit, $8.3 \%$ on the roadside and $8.3 \%$ in the bio-gas plant $(p<0.01)$. The existing practice of disposing droppings on road side result in loss of valuable nutrients, contamination of the surface and/or ground water, potential source of spread of poultry diseases, odour and aesthetic problems (Hossain and Ali, 2009).

Site of pit: Among pits, $70 \%$ situated at high land, $20 \%$ situated at low land and $10 \%$ situated at medium land. Pit is situated on high land was significantly higher than that on low land and medium land. Nitrate leaching into the ground water, non point source of phosphorous runoff into surface water bodies, and release of pathogenic microorganisms are problems encountered with improper management of pit (Hossain and Ali, 2009). The existing practice of disposing droppings in pit which situated at low land can result droppings wash out with rain water and cause environmental pollution (Alam et al., 2005).

Upper side of the pit: Among the pits, $80 \%$ had upper side opened and $20 \%$ had upper side closed. It appeared that lack of awareness of the farmers might be responsible for dumping droppings in open pit.

Use in field (compost): Among farmers, 55.6\% layer farmer applies droppings in the crop filed as compost, while rests $44.4 \%$ do not apply droppings in the crop filed. Droppings use as a soil fertilizer for crop production is due to the fact that it contains significant amounts of nutrients essential for plant growth (Hossain and Ali, 2009).

Composting period: It is evident (Table 3 ) that $40.0 \%$ farmers were in favour of three months composting, $40.0 \%$ preferred six months and $20 \%$ for a period of one year to compost droppings. Rahman (2007) suggested that in 60 days, composting gradually decreased DM.

Treatment of droppings: It is evident (Table 3 ) that $25.0 \%$ farmers treated infected droppings with lime prior to disposal, while $75.0 \%$ did not do any treatment.

Use of droppings: Among farmers, $36.8 \%$ sold, $26.3 \%$ gave free of cost, $10.5 \%$ used as fish feed, $5.3 \%$ both sold and gave free of cost, $5.3 \%$ both sold and used as fish feed, $5.3 \%$ both used as fish feed and gave free of cost, $5.3 \%$ sold, gave free of cost and used in bio-gas plant, $5.3 \%$ sold, used as fish feed and used in manufacturing fertilizer (Table 3). The finding indicated that droppings sold was significantly higher than others, possibly farmers considered that as simple. Alam et al., (2005) reported that droppings could be used as material of compost, source of organic fertilizer, feed for fish and used as fuel purpose. Sarker et al., (2009) reported that droppings could be sold, used as fish feed and used for crop production. DLS (2000) mentioned that droppings can be used as feed ingredient for cattle and as a fuel in powerhouse.

Droppings collected at free of cost: Among the free of cost collector, $37.5 \%$ was crop farmers, $37.5 \%$ was fisheries and rest $25.0 \%$ was crop plus fisheries farmers.

Droppings buyer: Among the buyers, $66.7 \%$ was involved with cultivating fish and the rest $33.3 \%$ was crop plus fish farmer.

Droppings price: Half of farmer received maximum droppings price in winter (Tk $53 / 50 \mathrm{~kg}$ bag), while other half received that in winter \& rainy season.

Inclusion of dropped feather into droppings: In 95.0\% cases dropped feathers were included in the droppings. Inclusion of dropped feather with droppings might be due to problem of separation.

Pollution by feed, droppings, dead hens, medical wastes and bad odour: Table 3 reveals that $95.0 \%$ respondent's are in opinion that feed do not cause environmental pollution, while $5.0 \%$ respondent's opined feed as an environment pollutant. About $65.0 \%$ respondents claimed droppings do not cause environmental pollution, while $35.0 \%$ gave opinion in the favour of environmental pollution. Hossain and Ali (2009) and Griffiths (2004) reported that faulty use of droppings can cause environmental pollution. Droppings are by far the number one waste problem, and its problems can be due to a number of different issues including disposal, odour, associated nuisances and soil, water and air pollution (Sims and Wolf, 1994; Henuk, 2001 and Bell, 2002). Majority (80.0\%) of the respondents opined that dead bird do not cause environmental pollution, $20.0 \%$ respondent's opinion in favour of environmental pollution (Table 3). Proper disposal of dead birds is a part of structural bio-security (Aziz and Ahmed, 2009). It was 
revealed that $75.0 \%$ respondent think that medical wastes do not cause environmental pollution, while $25.0 \%$ opined medical wastes as an environmental pollutant (Table 3 ). It was found that $90.0 \%$ respondents are in opinion that bad odour comes from the poultry farm do not cause environmental pollution, while $10.0 \%$ respondent reported bad odour as environmental pollutant. The opinion of bad odour's non contribution to environmental pollution might be due to their lack of awareness and ignorance. Nearby residents of large-scale poultry operations who experience these odours have less vigor and more tension, anger, depression, fatigue and confusion (Webb, 1998).

Table 3. Dropping related management by the farmers

\begin{tabular}{|c|c|c|c|c|}
\hline \multirow[t]{2}{*}{ Items } & \multirow[t]{2}{*}{ Category } & \multicolumn{2}{|c|}{ Respondents $(\mathrm{n}=20)$} & \multirow[t]{2}{*}{ Chi-test } \\
\hline & & Number & Per cent & \\
\hline \multirow[t]{2}{*}{ Age group of bird } & Same & 18 & 90.0 & \multirow[t]{2}{*}{$12.80^{* *}$} \\
\hline & Different & 2 & 10.0 & \\
\hline \multirow[t]{3}{*}{ Type of housing } & Single storied & 17 & 85.0 & \multirow[t]{3}{*}{$24.11^{* *}$} \\
\hline & Multi-storied & 2 & 10.0 & \\
\hline & Single+Multi-storied & 1 & 5.0 & \\
\hline \multirow[t]{4}{*}{ Type of ventilation } & Ceiling fan & 15 & 75.0 & \multirow[t]{4}{*}{$27.20^{* *}$} \\
\hline & Ceiling+Table fan & 1 & 5.0 & \\
\hline & Ceiling +Stand fan & 3 & 15.0 & \\
\hline & Ceiling+Table+Stand fan & 1 & 5.0 & \\
\hline \multirow[t]{3}{*}{ Frequency of droppings collection } & Alternative day & 12 & 60.0 & \multirow[t]{3}{*}{$9.11^{*}$} \\
\hline & Every day & 7 & 35.0 & \\
\hline & Two days interval & 1 & 5.0 & \\
\hline \multirow[t]{2}{*}{ Time of cleaning } & Morning & 18 & 90.0 & \multirow[t]{2}{*}{$12.80^{* *}$} \\
\hline & Noon & 2 & 10.0 & \\
\hline \multirow[t]{5}{*}{ Cleaning responsibility } & Male labour & 14 & 70.0 & \multirow[t]{5}{*}{$31.50^{* *}$} \\
\hline & Female labour & 2 & 10.0 & \\
\hline & Male farmer & 2 & 10.0 & \\
\hline & Farmer's wife & 1 & 5.0 & \\
\hline & Buyer & 1 & 5.0 & \\
\hline \multirow[t]{2}{*}{ Problem for cleaning } & Yes & 14 & 70.0 & \multirow[t]{2}{*}{$3.20^{\mathrm{NS}}$} \\
\hline & No & 6 & 30.0 & \\
\hline \multirow[t]{2}{*}{${ }^{1}$ Type of problem } & Odour & 3 & 50.0 & \\
\hline & Gas & 3 & 50.0 & \\
\hline \multirow[t]{2}{*}{ Tool for cleaning } & Belcha & 17 & 85.0 & \multirow[t]{2}{*}{$9.8^{\star \star}$} \\
\hline & Water+Belcha & 3 & 15.0 & \\
\hline \multirow[t]{8}{*}{ Disinfectant use } & Nothing & 5 & 25.0 & \multirow[t]{8}{*}{$8.0^{\mathrm{NS}}$} \\
\hline & Savlon & 3 & 15.0 & \\
\hline & Phenol & 2 & 10.0 & \\
\hline & Potash & 2 & 10.0 & \\
\hline & Potash+Savlon & 1 & 5.0 & \\
\hline & Potash+Bleaching powder & 1 & 5.0 & \\
\hline & $\begin{array}{l}\text { Potash+Savlon+Bleaching } \\
\text { powder }\end{array}$ & 1 & 5.0 & \\
\hline & Others & 5 & 25.0 & \\
\hline \multirow[t]{2}{*}{${ }^{2}$ Seasonal problem } & Winter & 3 & 60.0 & \multirow[t]{2}{*}{$0.20^{\mathrm{NS}}$} \\
\hline & Summer & 2 & 40.0 & \\
\hline${ }^{3}$ Site of disposal & Pit & 10 & 83.3 & $13.50^{* *}$ \\
\hline & Road side & 1 & 8.3 & \\
\hline & Bio-gas plant & 1 & 8.3 & \\
\hline${ }^{4}$ Site of pit & Low land & 2 & 20.0 & $6.19^{*}$ \\
\hline & Medium land & 1 & 10.0 & \\
\hline & High land & 7 & 70.0 & \\
\hline
\end{tabular}

NS, $\mathrm{P}>0.05 ;{ }^{*}, \mathrm{P}<0.05 ;{ }^{* *}, \mathrm{P}<0.01$ 
Table 3. (contd.)

\begin{tabular}{|c|c|c|c|c|}
\hline \multirow[t]{2}{*}{ Item } & \multirow[t]{2}{*}{ Category } & \multicolumn{2}{|c|}{ Respondents(n=20) } & \multirow[t]{2}{*}{ Chi-test } \\
\hline & & Number & Per cent & \\
\hline \multirow[t]{2}{*}{${ }^{4}$ Upper side of the pit } & Open & 8 & 80.0 & \multirow[t]{2}{*}{$3.60^{\mathrm{NS}}$} \\
\hline & Close & 2 & 20.0 & \\
\hline \multirow[t]{2}{*}{${ }^{5}$ Apply field (compost) } & Yes & 5 & 55.6 & \multirow[t]{2}{*}{$0.12^{\mathrm{NS}}$} \\
\hline & No & 4 & 44.4 & \\
\hline \multirow[t]{3}{*}{${ }^{2}$ Composting period } & Three month & 2 & 40.0 & \multirow[t]{3}{*}{$0.41^{\mathrm{NS}}$} \\
\hline & Six month & 2 & 40.0 & \\
\hline & One year & 1 & 20.0 & \\
\hline \multirow[t]{2}{*}{${ }^{6}$ Treatment of droppings } & Yes & 1 & 25 & \multirow[t]{2}{*}{$1.00^{\mathrm{NS}}$} \\
\hline & No & 3 & 75 & \\
\hline \multirow[t]{8}{*}{${ }^{7}$ Use of droppings } & Sale & 7 & 36.8 & \multirow[t]{8}{*}{$15.97^{*}$} \\
\hline & Give at free cost & 5 & 26.3 & \\
\hline & Fish feed & 2 & 10.5 & \\
\hline & Sale+ Give at free cost & 1 & 5.3 & \\
\hline & Sale+ Fish feed & 1 & 5.3 & \\
\hline & Fish feed + Give at free & 1 & 5.3 & \\
\hline & Sale+ Give free+Bio-gas & 1 & 5.3 & \\
\hline & Sale+ Fish feed+M. fertilizer & 1 & 5.3 & \\
\hline \multirow[t]{3}{*}{${ }^{8}$ Droppings collected at free cost } & Crop farmer & 3 & 37.5 & \multirow[t]{3}{*}{$0.25^{* *}$} \\
\hline & Fisheries & 3 & 37.5 & \\
\hline & Crop farmer +Fisheries & 2 & 25.0 & \\
\hline \multirow[t]{2}{*}{${ }^{3}$ Droppings buyer } & Fisheries & 8 & 66.7 & \multirow[t]{2}{*}{$1.34^{\mathrm{NS}}$} \\
\hline & Crop farmer +Fisheries & 4 & 33.3 & \\
\hline \multirow[t]{2}{*}{${ }^{9}$ Maximum droppings price } & Winter & 1 & 50.0 & \\
\hline & Winter +Rainy season & 1 & 50.0 & \\
\hline \multirow{2}{*}{$\begin{array}{l}\text { Inclusion of dropped feather } \\
\text { into droppings }\end{array}$} & Yes & 19 & 95.0 & \multirow[t]{2}{*}{$16.20^{* *}$} \\
\hline & No & 1 & 5.0 & \\
\hline \multirow[t]{2}{*}{ Pollution by feed } & Agree & 1 & 5.0 & \multirow[t]{2}{*}{$16.20^{* *}$} \\
\hline & Disagree & 19 & 95.0 & \\
\hline \multirow{2}{*}{$\begin{array}{l}\text { Pollution } \\
\text { by droppings }\end{array}$} & Agree & 7 & 35.0 & \multirow[t]{2}{*}{$1.80^{\mathrm{NS}}$} \\
\hline & Disagree & 13 & 65.0 & \\
\hline \multirow{2}{*}{$\begin{array}{l}\text { Pollution by } \\
\text { dead bird }\end{array}$} & Agree & 4 & 20.0 & \multirow[t]{2}{*}{$7.20^{* *}$} \\
\hline & Disagree & 16 & 80.0 & \\
\hline Pollution by medical wastes & Agree & 5 & 25.0 & $5.00^{*}$ \\
\hline & Disagree & 15 & 75.0 & \\
\hline Pollution by & Agree & 2 & 10.0 & $12.8^{* *}$ \\
\hline bad odour & Disagree & 18 & 90.0 & \\
\hline Measure to minimize pollution & Clean regularly & 16 & 80.0 & $7.20^{\star *}$ \\
\hline & $\begin{array}{lll}\text { Clean regularly } & \text { +Spray } \\
\mathrm{CaO} & & \\
\end{array}$ & 4 & 20.0 & \\
\hline
\end{tabular}

Measure to minimize pollution: It was signaled that $80.0 \%$ respondent clean farm regularly to minimize environmental pollution, while $20.0 \%$ clean regularly \& spray CaO. Proper management of poultry waste helps to protect the environment from pollution (Hossain and Ali, 2009).

\section{Conclusion}

The findings of the study reveal that there is no recommended cleaning method for layer farms in study area. Farmers are using variable methods without having any idea about their efficacy. Amount of dropping is increasing with the increase of farms and poultry population. It is a real problem for aesthetic, public septic and environmental point of view. Relative liability and benefit of droppings disposal methods is need to be assessed and evaluated. Cleaning technique and tools need to be modernized for efficient 
and cost effective cleaning. Standard method needed to be introduced for proper treatment and use of droppings to maximize its use and benefit. Poultry farmers need training for proper disposal of poultry droppings. Main constraints of droppings disposal are lack of awareness, cleaning problem, no specific use of disinfectant, soil pollution by leaching, lack of facilities for forced water cleaning, open pit and disposing on roadside. So, management body should take prime role for proper droppings disposal.

\section{Recommendation}

Droppings disposal is an acute problem and it is increasing day by day. If nobody take care about it and the system continue for long time, it may be threat to the environment. So, it is high time to take some necessary steps for better droppings disposal. To improve the present droppings disposal some measures are needed to be adopted. Based on the above conclusions some specific recommendations are proposed to dispose droppings in an appropriate way is given below:

i) The shed must be cleaned regularly and disinfected;

ii) Pit should be located on high land with upper side need to be covered;

iii) Increasing awareness among farmers could stop throwing droppings in the road side;

iv) Best use of droppings could be ensured by developing proper composting methods and using it in bio-gas plant;

v) Farmers awareness should be made through; a) Government (GO) agencies by personal contact, group discussion, seminar, symposium and workshop in rural areas b) Non-government (NGO) agencies by poster, leaflet etc. in rural farmers c) Government (GO) and Non-government (NGO) could also use mass media (Television, Radio, Newspaper);

vi) The legislation and guidelines regarding the establishment of poultry farm should be governed by the Government of Bangladesh through National Poultry Policy.

\section{References}

Akteruzzaman, M., Miah, M.A.M., Hossain, M.M., Jebunnahar and Fattah, K. 2009. Impact of training on poultry farming for improving livelihood of the smallholders in rural Bangladesh. In: Proceedings of the $6^{\text {th }}$ International Poultry Show and Seminar. The World Poultry Science Association, Bangladesh Branch, Dhaka, Bangladesh. pp. 40.

Alam, M.B., Hossain, M.M. and Sattar, M.A. 2005. Litter management of some broiler farms at Mymensingh Sadar Upazila in relation to environment. Bangladesh Journal of Environmental Science, 11(2): 446-449.

Azad, M.A.K. 2003. Participation of women in Decision in making Regarding Farming Activities in two selected villages of Patuakhali District. M. S. (Ag. Ex. Edu.) Thesis, Dept. of Agricultural Extension Education. Bangladesh Agricultural University, Mymensingh.

Aziz, M.A. and Ahmed, S.U. 2009. Biosecurity in poultry farm management. In: Proceedings of $6^{\text {th }}$ International Poultry Show and Seminar, The World Poultry Science Association, Bangladesh Branch, Dhaka, Bangladesh. pp. 223-227.

BBS (Bangladesh Bureau of Statistics). 2005. Statistical Yearbook of Bangladesh. 2007. Planning division, Ministry of Planning, Govt. of the People's Republic, Bangladesh, Dhaka.

Bell, D.D. 2002. Waste management. In: Commercial Chicken Meat and Egg Production, $5^{\text {th }}$ edition, (Bell, D. D. and Weaver, Jr. W. D., Eds), Kluwer Academic Publishers, Massachusetts, USA, pp. 149-167.

Bell, D.D. and Weaver, Jr. W.D. 2002. Cage Management for Layers. In: Commercial Chicken Meat and Egg Production, Kluwer Academic Publishers, Norwell, Massachusetts, 02061 USA, $5^{\text {th }}$ edition pp. 1028-1029.

Bhuyian, M.F.A. 2007. Environment-friendly poultry waste management: prospect of organic fertilizer (Poribesh sohayok poultry borjo babosthapona, joybo sarer sombhabona). Farm House (A monthly Agribusiness Magazine), Dhaka-1212. 1: 35-36.

DLS (Department of Livestock Services). 2000. General information related to livestock. Monthly livestock and fisheries bulletin, published by fisheries and livestock information office, Kharmarbhai, Farmgate, Dhaka, Bangladesh.

Griffiths, N. 2004. Poultry litter: Best practice guidelines for using poultry litter on pastures. NSW Agriculture. 4: 212.

Hamid, M.A. 1997. Farmer's awareness on environment pollution, A Study in Bangladesh. Asia Pacific Journal of Rural Development, 7(2): 107-117.

Henuk, Y.L. 2001. Nutrient adjustments of the diets fed to cage and barn laying hens to decrease waste. PhD Thesis, University of Queensland, Gatton.

Hossain, M.M. and Ali, M.S. 2009. Waste management in poultry farms and environmental protection in Bangladesh. In: Proceedings of the $6^{\text {th }}$ International Poultry Show and Seminar. The World Poultry Science Association, Bangladesh Branch, Dhaka, Bangladesh. pp. 199-202. 
Khaleduzzaman, A.B.M. and Khandaker, Z.H. 2009. Commercial feed production and quality control: present status and future prospects in Bangladesh. In: Proceedings of the $6^{\text {th }}$ International Poultry Show and Seminar. The World Poultry Science Association, Bangladesh Branch, Dhaka, Bangladesh. pp. 2.

North, M.O. and Bell, D.D. 1990. Cage Management. In: Commercial Chicken Production Manual, Chapman and Hall. Dept. B. C., 115 Fifth Avenue, New York, NY-10003, USA, $4^{\text {th }}$ Edition, pp. 352.

Rahman, M. A. 2007. Development of Convenient composting method using broiler litter.An M. S. Thesis. Dept. of Animal Science. Bangladesh Agricultural University, Mymensingh.

Sarker, B.C., Alam, M.A., Rahman, M.M., Tariqul Islam, A.F.M. and Chowdhury, M.G.F. 2009. Waste Management of Commercial Poultry Farms in Bangladesh. Journal of innovation and development strategy, 2(3): 34-37.

Shahidullah, M. 1987. The Production and Making Behaviour of the Poultry Farmers in Boilor Union of Mymensingh District. M. S. (Ag. Ex. Ed.). Thesis. Dept. of Agricultural Extension Education. Bangladesh Agricultural University, Mymensingh.

Sims, J.T. and Wolf, D.C. 1994. Poultry waste management: agricultural and environmental issues. Advances in Agronomy, 52: 183.

Vest, L., Merka, B. and Segars, W.L. 1994. Poultry waste: Georgia's 50 million dollar forgotten crop. The University of Georgia and College of Agricultural and Environmental Science. Comperative Extension Service Leaflet 206/july, 1994.

Webb, D. 1998. "Alliance for a Responsible Poultry Industry": Manure Management in Harmony with the Environment and Society. The Soil and Water Conservation Society, West North Central Region, Ames lowa, pp. 313-314.

Yasmin, L. 1987. Relationship of Selected Characteristics of Backyard Poultry Farming with Knowledge and Poultry Production. M. S. (Ag. Ex. Ed.). Thesis. Dept. of Agricultural Extension Education .Bangladesh Agricultural University, Mymensingh. 